\title{
Sowing techniques effect on growth and yield components of field pea cultivars under climate conditions of Quetta- Pakistan
}

\author{
Zulfiqar Ali Mastoi ${ }^{1 *}$, Abdul Sattar Khetran ${ }^{2}$, Rehmatullah Khetran ${ }^{3}$, \\ Muhammad Arif Kakar ${ }^{4}$, Mujeeb-ur-Rehman Baloch ${ }^{5}$ and \\ Mohammad Saleem Mastoi ${ }^{6}$ \\ 1. Directorate of Agriculture Research, Usta Mohammed, Jaffarabad, Balochistan-Pakistan \\ 2. Directorate of Agriculture Research Cereal Crops, Agriculture Research Institute (A.R.I), Sariab, Quetta, \\ Balochistan-Pakistan \\ 3. Directorate of Agriculture Research Fruit, Agriculture Research Institute (A.R.I), Sariab, Quetta, Balochistan- \\ Pakistan \\ 4. Directorate of Agriculture Research Pulses, Agriculture Research Institute (A.R.I), Sariab, Quetta, \\ Balochistan-Pakistan \\ 5. Directorate of Agriculture Research Water Management \& High Efficency, Agriculture Research Institute \\ (A.R.I), Sariab, Quetta, Balochistan-Pakistan \\ 6. Department of Agronomy, Sindh Agriculture University Tandojam-Pakistan \\ *Corresponding author's email: historian106zz@gmail.com \\ Citation \\ Zulfiqar Ali Mastoi, Abdul Sattar Khetran, Rehmatullah Khetran, Muhammad Arif Kakar, Mujeeb-ur-Rehman \\ Baloch and Mohammad Saleem Mastoi. Sowing techniques effect on growth and yield components of field pea \\ cultivars under climate conditions of Quetta-Pakistan. Pure and Applied Biology. Vol. 7, Issue 2, pp754-764. \\ http://dx.doi.org/10.19045/bspab.2018.70094
}

\begin{tabular}{llll}
\hline \hline Received: 07/04/2018 & Revised: 05/06/2018 & Accepted: 21/06/2018 & Online First: 26/06/2018 \\
\hline \hline
\end{tabular}

\section{Abstract}

The experiment was carried out at Directorate of Agriculture Research Pulses, A.R.I, Sariab, Quetta-Pakistan during rabi season-2017 to check the effect of the three different sowing techniques/ ways (broadcasting, drill and ridge sowing) on yield components \& growth of three cultivars (Local, Italian and Sel-190) of field pea. The randomized complete block design (RCBD) with three replications was used. The size of plot was $10.5 \mathrm{~m}^{2}$. Field pea cultivars were significant $(\mathrm{P}<0.05)$ influenced by three different sowing methods. Regarding the sowing methods the pea crop sown under ridge method got the highest yield components in all traits like (89.70\%) seed germination, (7.35) branches per plant, (29.45) pods plant ${ }^{-1},(5.92)$ seeds $\operatorname{pod}^{-1},(6.34)$ fresh pod yield $\mathrm{kg} \mathrm{plot}^{-1},(175.79)$ gram (g) seed index and (4109.86) seed yield $\mathrm{kg} \mathrm{ha}^{-1}$. The pea crop sown under broadcasting method got lowest yield components in all traits like $(87.82 \%)$ seed germination, (5.51) branches per plant, (24.08) pods plant ${ }^{-1},(5.13)$ seeds pod $^{-1}$, fresh pod yield (6.00) $\mathrm{kg} \mathrm{plot}^{-1}$, (156.20) gram (g) seed index and (3054.86) seed yield $\mathrm{kg} \mathrm{ha}^{-1}$. Regarding the yield components the cultivar 'Sel-190' got first rank, the 'Italian' cultivar second and the 'Local' cultivar gained third rank in all their traits. On the basis of seed yield $\mathrm{kg} \mathrm{ha}^{-1}$ the interaction of ridge method $\times$ 'Sel-190' cultivar showed superior results over rest of the interactions. It was concluded that ridge sowing method proved to be superior over drilling and broadcasting with highest seed yield (4109.86) $\mathrm{kg} \mathrm{ha}^{-1}$.

Keywords: Field pea cultivars; Pea growth; Sowing techniques; Yield component 


\section{Introduction}

The legumes having high protein rates are the vital sources of food for poor and plant nitrogen; and play an important role in crop rotations for maintaining soil fertility. Peas green pods are used as vegetable and their dried form, is a portentous pulse. Field Peas (Pisum sativum L.) belongs to family leguminoseae is a grain legume and is the native of central or Southeast Asia [1]. Peas shows its growth attributes best in a cool climate and in the presence of abundance moisture contents as well. The concerned crop is extensively sown in temperate regions as fresh green seed consumptions. Pea is consider as tremendous human being foodstuff, consumed on the basis of vegetable and the preparation of soup as well. Regarding to nutritional composition of pea, it is naturally constituted $27.80 \%$ protein, $42.65 \%$ multifaceted carbohydrate, antioxidant compounds, nutritional fibers, mineral deposits and vitamins [2, 3]. The field peas (Pisum sativum L.) used to grown for thousands years. Its areas of farming had been formed in southeastern Turkey and Syria [4]. In Pakistan, especially in Punjab, the pea is consider the most chief vegetable on account of its nutritional value that potently builds the best economic status of the farmer community. According to marketable demand and nutritive importance it is regards as commonly known vegetable [5]. The nutritional status of pea shows that its $100 \mathrm{~g}$ uncooked green pea has $(80 \mathrm{kcal})$ energy, $(5.4 \mathrm{mg})$ protein, $(0.4 \mathrm{~g})$ fat, $(5.7 \mathrm{~g})$ sugars, $(22.9 \%)$ protein etc. whereas dried out peas constituted water $(10.9 \%)$, fat $(1.4 \%)$, crude fiber (1.4\%), and ash (2.7\%)" [6]. Rresultantly, this vegetable is highly loved by the masses but the cultural practices for commercial purposes is not latest scientific manners yet. In addition, the Pakistan has less yield per acre of pea than its potential as compared to the advanced countries of the world. Resultantly, to provide the consumption requirement to the masses, the pea is imported. The barriers behind the high productivity of the pea vegetable is improper management practices [7]. Apparently, the most chief cause of low production is the traditional sowing methods which our growers not manipulate on latest scientific ways. The pea crop growing is prevalent in the regions comprising the climate of warmer and mild. Because, the climatic agent which hinder the limited farming, pea production are relatively low and high temperature. For pea growth and development attributes a dry climate is not fit for it especially, while pod and flowering development. Additionally, the role of high yielding and early maturing varieties is decisive, because cumulative mean temperature requirements for flowers formation varied for different cultivars; and dry periods substantially diminish yields. On the other hand, yields can be augmented by adoption of those peas' varieties having early flowering and maturity attributes [8]. The pea cultivation has various ways but mostly sowing is carried out ridge sowing, broadcasting seed, drilling in rows and dibbling method of sowing. Peas are planted $1 \mathrm{ft}$ to $11 / 2 \mathrm{ft}$ apart in rows. In case of peas planting on large bed, these can be planted in a zig-zag pattern with 12 "-18" between the plants by drilling method. Peas are not normally thinned and it is compulsory to plant the peas at the proper spacing to begin with to keep away from wasting seed [9]. Sharma and Rajput [8] reported that sowing methods has significant impact on the pea enlargement and production attributes and the production responses varied noticeably under different tillage methods and sowing techniques. The El-Habbasha et al. [10] concluded that sowing of peas on ridges in line resulted in higher yields as compared to other planting methods. The Varshney [11] observed that sowing methods and spacing between rows and plants affects the crop performance significantly. The Devi et al. [12] found that inter and intra row spacing and sowing methods have significant effect on the performance of field peas. The Ghaffar [13] reported that that raised bed under wider row spacing proved to be the 
superior sowing pattern as compared to flatbed system, but row spacing beyond 60 $\mathrm{cm}$ did not show economic impact on pods yield because of reduced plant population. Therefore, sowing of peas in raised bed system at $60 \mathrm{~cm}$ row spacing was considered as an effective sowing pattern. The Kuczkowski et al. [7] used broadcasting, drilling ridges and dibbling of seeds were used. The results showed that regardless the cultivars of common pea and spacing arrangements, drilling seeds on ridges proved to be effective in producing higher yields in pea as compared to other management techniques. The Gan et al. [14] suggest that ridge-furrow systems are an innovative approach for increasing crop water availability, improving soil productivity, and enhancing food security for arid and semiarid rain-fed areas. Taking into consideration, the sowing techniques value in crop management, the research study was conducted to examine the effect on three different sowing methods on the development and production attributes of field pea cultivars under Quetta-Pakistan conditions.

\section{Materials and methods}

The research experiment was carried out to examine the effect of three different sowing techniques/ methods on the development and production attributes of field pea cultivars during rabi year 2017 at the experimental fields of Directorate of Agriculture Research Pulses, A.R.I, Sariab, Quetta. The randomized complete block design-factorial, comprised Factor-A (Sowing method i.e SIM1= broadcasting, SIM2= drilling, SIM3= ridge); and FactorB (Cultivars i.e V1=local, V2= Italian, V3= Sel-190. The experiment plot size was $3.0 \mathrm{~m}$ $\mathrm{x} 3.5 \mathrm{~m}=\left(10.5 \mathrm{~m}^{2}\right)$. The selected experimental land was well ploughed, the clods were crushed, and the weeds were removed by levelling the land to make the soil surface levelled for uniform irrigation and fertilizer distribution. Three types of seedbeds were prepared keeping in view the sowing methods and each sowing method was practiced/applied on three field pea cultivars, and replicated thrice. Each bed was distributed by $(60 \mathrm{~cm})$.

\section{Observations}

Procedure for recording observation is given below:

\section{Seed germination $(\%)$}

The germination of seed percentage was calculated by multiplying the numbers of emerged seeds into 100 divided by total number of seeds, in each plot.

\section{Number of branches per plant}

At the maturity stage of the pea the number of branches plant per plant of the labelled plants in each plot is counted.

\section{Number of pods per plant}

At the time of pea's maturity, the pods number per plant of labelled plants was counted in each plot.

\section{Number of seeds per pod}

At the time of ripeness pods number per plants of labeled plants were counted.

\section{Fresh pod yield per plot $(\mathbf{k g})$}

Fresh pods were cutted and weighed individually in each plot and worked out for all the plots in kilograms.

\section{Seed index (1000 seeds, g)}

Seed index value was observed on the basis of 1000 seeds manually separated by counting in each plot and were weighed to record seed index in grams.

\section{Seed yield (kg ha-1)}

Seed yield (kg ha-1) was calculated by by means of the below given formula:

Seed yield (kgha-1) $=$ Seed yield plot- $1(\mathrm{~kg}) \times 10000$ Plot size (m2)

The whole calculation/ data was documented on the basis of five selected plants in each bed. Statistical analysis Statistical analysis of data was carried out by using L.S.D (Least Significant Differences) test, as per the statistical methods developed by Gomez and Gomez (1984). Using Mstat-C Computer Software performed all the statistical tests.

\section{Results}

The effect of various sowing techniques/ methods (broadcasting, drilling and ridge sowing) on the growth and yield attributes of field pea cultivars (Local, Italian and Sel190) was investigated during Rabi year 2017. The observations were recorded on various parameters of economic importance 
including seed germination (\%), number of branches per plant, number of pods per plant, number of seeds per pod, fresh pod yield $\left(\mathrm{kg} \mathrm{plot}^{-1}\right)$, seed index (1000 seeds weight $\mathrm{g})$ and seed yield $\left(\mathrm{kg} \mathrm{ha}^{-1}\right)$. After statistical analysis, the meaningful data were formed and presented in the following given (Tables 1 to 7 ).

\section{Sowing methods}

The effect of sowing methods on the seed germination percentage of field pea cultivars was examined and the results are presented in the below given (Table 1). Statistical analysis suggested that the effect of sowing methods on seed germination was non-significant $(\mathrm{P}>0.05)$, while field pea cultivars differed significantly $\quad(\mathrm{P}<0.05) \quad$ for $\quad$ seed germination and interactive effect of sowing methods $\times$ cultivars was also nonsignificant $(\mathrm{P}>0.05)$. Relatively higher seed germination $(89.70 \%)$ was observed in plots sown by ridge method as compared to broadcasting (87.82\%) and drilling method (86.14\%). Similarly, cultivars differed significantly $(\mathrm{P}<0.05)$ for seed germination and 'Italian' cultivar resulted higher germination $(90.85 \%)$ as compared to cultivars 'Local' (86.76\%) and 'Sel-190' (86.04\%). Treatment interaction (Ridge method $\times$ 'Italian' cultivar) resulted in maximum seed germination $(92.55 \%)$ and interaction (Drilling method $\times$ 'Local' cultivar) resulted in lowest seed germination (84.12\%). Apparently, there was no association of sowing methods with the seed germination ability under normal tillage recommendations; and generally the seed germination is influenced by the seed viability. The differences in seed germination percentage between 'Local' and 'Sel-190' cultivars was nonsignificant $(\mathrm{P}>0.05)$ and significant $(\mathrm{P}<0.05)$ when these cultivars were compared with "Italian' cultivar.

Table 1. Seed germination (\%) of field pea cultivars as affected by three different

\begin{tabular}{|c|c|c|c|c|}
\hline \multirow{2}{*}{ Sowing Method } & \multicolumn{3}{|c|}{ Cultivars } & \multirow{2}{*}{ Mean } \\
\cline { 2 - 4 } & Local & Italian & Sel-190 & \\
\hline Broadcasting & 87.17 & 90.66 & 85.63 & $\mathbf{8 7 . 8 2}$ \\
\hline Drilling & 84.12 & 89.35 & 84.96 & $\mathbf{8 6 . 1 4}$ \\
\hline Ridge & 89.00 & 92.55 & 87.55 & $\mathbf{8 9 . 7 0}$ \\
\hline Mean & $\mathbf{8 6 . 7 6} \mathbf{b}$ & $\mathbf{9 0 . 8 5} \mathbf{~ a}$ & $\mathbf{8 6 . 0 4} \mathbf{b}$ & - \\
\hline
\end{tabular}

\begin{tabular}{|c|c|c|c|}
\hline & Sowing method $(\mathbf{M})$ & Cultivars $(\mathbf{C})$ & $\mathbf{M} \times \mathbf{C}$ \\
\hline S.E. \pm & 1.67 & 1.67 & 2.90 \\
\hline LSD 0.05 & - & 3.55 & - \\
\hline LSD 0.01 & - & & \\
\hline
\end{tabular}

Values followed by same letters do not differ significantly at 0.05 probability level

Development of fruiting bodies on a plant is mainly associated with the number of branches and obviously more branching will result greater fruit bearing. The effect of sowing methods on the number of branches per plant was determined and the data is shown in the below given (Table 2). Statistical analysis demonstrated that the effect of sowing methods and cultivars on branches per plant was significant $(\mathrm{P}<0.05)$, while non-significant $(\mathrm{P}>0.05)$ effect was observed for sowing method $x$ cultivar interaction. Significantly maximum branches plant $^{-1}$ (7.35) were achieved under ridge method of sowing field pea, while drilling method resulted in 6.19 branches plant $^{-1}$ and minimum branches plant ${ }^{-1}$ (5.51) were observed in broadcasting method. In cultivars, the more branches plant ${ }^{-1}$ were observed in cultivar 'Sel-190' (6.52) and "Italian" (6.48), while minimum branches plant ${ }^{-1}$ 
(6.05) were noted in 'Local' cultivar. Treatment interaction (Ridge method $x$ 'Sel-190' cultivar) resulted in maximum branches plant ${ }^{-1}$ (7.73) and interaction (Broadcasting method $\times$ 'Local' cultivar) resulted in lowest branches plant ${ }^{-1}$ (5.30). It was observed that the field pea responded more positively to ridge sowing method for branches per plant than broadcasting and drilling methods. On the other hand, genetically, similar $(\mathrm{P}>0.05)$ response of cultivars 'Italian' and 'Sel-
190 ' to sowing methods was observed. Under ridge sowing method, the plants intercept light, utilized the nutrients and available moisture more efficiently than other sowing methods, and proper aeration impacted positively to have better branching. The differences in branches per plant between 'Italian' and 'Sel-190' cultivars was non-significant $(\mathrm{P}>0.05)$ and significant $(\mathrm{P}<0.05)$ when these cultivars were compared with "Local' cultivar.

Table 2. Number of branches per plant of field pea cultivars as affected by three different sowing methods

\begin{tabular}{|c|c|c|c|c|}
\hline \multirow{2}{*}{ Sowing methods } & \multicolumn{3}{|c|}{ Cultivars } & \multirow{2}{*}{ Mean } \\
\cline { 2 - 4 } & Local & Italian & Sel-190 & \\
\hline Broadcasting & 5.30 & 5.70 & 5.53 & $\mathbf{5 . 5 1} \mathbf{~ c}$ \\
\hline Drilling & 5.93 & 6.35 & 6.30 & $\mathbf{6 . 1 9}$ b \\
\hline Ridge & 6.93 & 7.40 & 7.73 & $\mathbf{7 . 3 5}$ a \\
\hline Mean & $\mathbf{6 . 0 5} \mathbf{b}$ & $\mathbf{6 . 4 8} \mathbf{a}$ & $\mathbf{6 . 5 2} \mathbf{a}$ & - \\
\hline
\end{tabular}

\begin{tabular}{|c|c|c|c|}
\hline & Sowing methods (M) & Cultivars (C) & $\mathbf{M} \times \mathbf{C}$ \\
\hline S.E. \pm & 0.13 & 0.13 & 0.23 \\
\hline LSD 0.05 & 0.28 & 0.28 & - \\
\hline LSD 0.01 & 0.39 & 0.39 & - \\
\hline
\end{tabular}

Values followed by same letters do not differ significantly at 0.05 probability level

The results in regards to number of pods per plant of field pea cultivars as influenced by various sowing methods are presented in the following (Table 3). Statistical analysis indicated that sowing method and cultivar effect on pods per plant was significant $(\mathrm{P}<0.05)$, while nonsignificant $(\mathrm{P}>0.05)$ effect was observed for sowing method $\times$ cultivar interaction. Significantly maximum pods per plant (29.45) of field pea were obtained under ridge method, while drilling method resulted in (25.76) pods plant $^{-1}$ and minimum pods plant $^{-1}$ (24.08) were observed in broadcasting method. The cultivar effect indicated that pods plant ${ }^{-1}$ were maximum (28.61) in 'Italian' cultivar, while lesser pods plant ${ }^{-1}$ (27.07) were observed in "Sel-190" and 'Local' (23.61) cultivars. Treatment interaction
(Ridge method $\times$ 'Italian' cultivar) resulted in maximum pods plant $^{-1}(31.15)$ and interaction (Broadcasting method $x$ 'Local' cultivar) resulted in lowest pods plant $^{-1}$ (20.67). In case of pods plant ${ }^{-1}$, the field pea cultivars responded more positively to ridge sowing method as compared to drilling and broadcasting; while regardless the sowing methods, 'Italian' cultivar produced more pods per plant than 'Sel-190' and 'Local' cultivars. However, this greater number of pods plant $^{-1}$ under ridge method and 'Italian" or 'Sel-190' field pea cultivars was mainly associated with the branches per plant. There were linear statistical differences $(\mathrm{P}<0.01)$ for pods per plant between sowing methods as well as field pea cultivars. 
Table 3. Number of pods per plant of field pea cultivars as influenced by three different sowing methods

\begin{tabular}{|c|c|c|c|c|}
\hline \multirow{2}{*}{ Sowing methods } & \multicolumn{3}{|c|}{ Cultivars } & \multirow{2}{*}{ Mean } \\
\cline { 2 - 4 } & Local & Italian & Sel-190 & \\
\hline Broadcasting & 20.67 & 27.10 & 24.47 & $\mathbf{2 4 . 0 8}$ c \\
\hline Drilling & 23.14 & 27.58 & 26.58 & $\mathbf{2 5 . 7 6}$ b \\
\hline Ridge & 27.04 & 31.15 & 30.16 & $\mathbf{2 9 . 4 5}$ a \\
\hline Mean & $\mathbf{2 3 . 6 1} \mathbf{c}$ & $\mathbf{2 8 . 6 1} \mathbf{a}$ & $\mathbf{2 7 . 0 7}$ b & - \\
\hline
\end{tabular}

\begin{tabular}{|c|c|c|c|}
\hline & Sowing methods (M) & Cultivars (C) & $\mathbf{M} \times \mathbf{C}$ \\
\hline S.E. \pm & 0.57 & 0.57 & 1.00 \\
\hline LSD 0.05 & 1.22 & 1.22 & - \\
\hline LSD 0.01 & 1.68 & 1.68 & - \\
\hline
\end{tabular}

Values followed by same letters do not differ significantly at 0.05 probability level

The data pertaining to the number of seeds per pod of field pea cultivars as affected by different sowing methods are given in the below given (Table 4). Statistical analysis showed that sowing method and cultivar effect as well as the effect of sowing method $\times$ cultivar interaction on seeds per pod was significant $(\mathrm{P}<0.05)$. The number of seeds pod ${ }^{-1}$ of field pea was highest 5.95 under ridge method, while drilling method resulted in 5.28 seeds per pod and lowest seeds pod $^{-1} 5.13$ were observed in broadcasting method. The cultivar effect indicated that seeds pod $^{-1}$ were maximum 6.15 in 'Sel-190' cultivar, while lesser seeds pod ${ }^{-1} 5.41$ and 4.77 were observed in "Italian" and 'Local' cultivars respectively. Treatment interaction (Ridge method $\times$ 'Sel-190' cultivar) resulted in maximum seeds pod $^{-1} 6.85$ and interaction (Broadcasting method $\times$ 'Local' cultivar) resulted in lowest seeds pod ${ }^{-1} 4.34$. In case of seeds per pod, the field pea cultivars responded more positively to ridge sowing method as compared to drilling and broadcasting; and irrespective of sowing techniques, 'Sel-190' cultivar produced more seeds per pod than 'Italian' and 'Local' cultivars. To some extent, these results are more influenced by number of branches and number of pods per plant. The LSD test suggested that the differences in seeds per pod between broadcasting and drilling were non- significant; and differences for this trait between 'Italian' and 'Sel-190' cultivars were also non-significant $(\mathrm{P}>0.05)$.

The results in relation to green pod yield per plot of field pea cultivars as influenced by various sowing methods are shown in below given (Table 5). Statistical analysis suggested that the effect of sowing methods, field pea cultivars as well as sowing method $\times$ cultivar interaction on green pod yield per plot was significant $(\mathrm{P}<0.05)$. The fresh pod yield $\mathrm{kg} \mathrm{plot}^{-1}$ of field pea was maximum $6.94 \mathrm{~kg}$ under ridge method, while drilling method produced fresh pod yield of $6.18 \mathrm{~kg} \mathrm{plot}^{-1}$ and minimum fresh pod yield plot $^{-1} 6.00$ $\mathrm{kg}$ was noted in broadcasting method. The cultivar effect showed that 'Sel-190' field pea cultivar produced highest green pod yield of $7.20 \mathrm{~kg} \mathrm{plot}^{-1}$, while fresh pod yield was relatively lower in "Italian" 6.33 $\mathrm{kg}$ plant $^{-1}$ and $5.59 \mathrm{~kg}$ yield in local and cultivars. Treatment interaction (Ridge method $\times$ 'Sel-190' cultivar) resulted in maximum fresh pod yield plot $^{-1} 8.02 \mathrm{~kg}$ and interaction (Broadcasting method $x$ 'Local' cultivar) resulted in lowest fresh pod yield plot $^{-1} 5.08 \mathrm{~kg}$. The higher fresh pod yield per plot was mainly associated with branches per plant, pods per plant and seeds per pod. The LSD test indicated that the differences in fresh pod yield per plot between broadcasting and drilling methods was non-significant $(\mathrm{P}>0.05)$ and 
significant $(\mathrm{P}<0.05)$ when compared with Ridge method; while linear differences were observed for this parameter between cultivars.

Table 4. Number of seeds per pod of field pea cultivars as influenced by three different sowing methods

\begin{tabular}{|c|c|c|c|c|}
\hline \multirow{2}{*}{ Sowing methods } & \multicolumn{3}{|c|}{ Cultivars } & \multirow{2}{*}{ Mean } \\
\cline { 2 - 4 } & Local & Italian & Sel-190 & \\
\hline Broadcasting & 4.34 & 5.49 & 5.56 & $\mathbf{5 . 1 3}$ b \\
\hline Drilling & 4.60 & 5.21 & 6.04 & $\mathbf{5 . 2 8}$ b \\
\hline Ridge & 5.34 & 5.53 & 6.85 & $\mathbf{5 . 9 2}$ a \\
\hline Mean & $\mathbf{4 . 7 7} \mathbf{b}$ & $\mathbf{5 . 4 1} \mathbf{a}$ & $\mathbf{6 . 1 5}$ a & - \\
\hline
\end{tabular}

\begin{tabular}{|c|c|c|c|}
\hline & Sowing methods (M) & Cultivars (C) & $\mathbf{M} \times \mathbf{C}$ \\
\hline S.E. \pm & 0.14 & 0.14 & 0.19 \\
\hline LSD 0.05 & 0.29 & 0.29 & 0.41 \\
\hline LSD 0.01 & 0.44 & 0.44 & - \\
\hline
\end{tabular}

Values followed by same letters do not differ significantly at 0.05 probability level

Table 5. Fresh pod yield (kg plot $\left.{ }^{-1}\right)$ of field pea cultivars as affected by different sowing methods

\begin{tabular}{|c|c|c|c|c|}
\hline \multirow{2}{*}{ Sowing methods } & \multicolumn{3}{|c|}{ Cultivars } & \multirow{2}{*}{ Mean } \\
\cline { 2 - 4 } & Local & Italian & Sel-190 & \\
\hline Broadcasting & 5.08 & 6.42 & 6.51 & $\mathbf{6 . 0 0}$ b \\
\hline Drilling & 5.30 & 6.10 & 7.07 & $\mathbf{6 . 1 8}$ b \\
\hline Ridge & 6.31 & 6.47 & 8.02 & $\mathbf{6 . 3 4} \mathbf{~ a}$ \\
\hline Mean & $\mathbf{5 . 5 9} \mathbf{c}$ & $\mathbf{6 . 3 3} \mathbf{b}$ & $\mathbf{7 . 2 0} \mathbf{a}$ & - \\
\hline
\end{tabular}

\begin{tabular}{|c|c|c|c|}
\hline & Sowing methods (M) & Cultivars (C) & M×C \\
\hline S.E. \pm & 0.15 & 0.15 & 0.27 \\
\hline LSD 0.05 & 0.33 & 0.33 & 0.57 \\
\hline LSD 0.01 & 0.46 & 0.46 & - \\
\hline
\end{tabular}

Values followed by same letters do not differ significantly at 0.05 probability level

The data in regards to seed index value (1000 seed weight, $\mathrm{g}$ ) of field pea cultivars as affected by different sowing methods are presented in Table-6. Statistical analysis demonstrated that the effect of sowing methods, cultivars as well as sowing method $\times$ cultivar interaction on seed index was significant $(\mathrm{P}<0.05)$. It is evident from the results in below given (Table 6) that seed index of field pea was maximum $175.79 \mathrm{~g}$ under ridge method, while seed index value was reduced under drilling method $160.87 \mathrm{~g}$ and broadcasting method $156.20 \mathrm{~g}$. The cultivar effect showed that 'Sel-190' field pea cultivar produced highest seed index value of $182.59 \mathrm{~g}$, while seed index value was relatively lower in "Italian" $164.80 \mathrm{~g}$ and 'Local' 145.47 g cultivars. Treatment interaction (Ridge method $\times$ 'Sel-190' cultivar) resulted in maximum seed index $194.67 \mathrm{~g}$ and interaction (Broadcasting method $\times$ 'Local' cultivar) resulted in lowest seed index $132.11 \mathrm{~g}$. It was observed that under ridge sowing method, the crop produced pods with bolder and heavier seeds as compared to drilling and broadcasting method, which was associated with the proper utilization of natural and applied soil nutrients. Under 
drilling and broadcasting methods, the plants receive excessive water, which improve plant foliage, but adverse effects on crop yield are expected. Hence, under ridge method, the crop utilizes the nutrients and moisture optimally and hence the plants yield heavier seeds.

Table 6. Seed index (1000 seed weight, $\mathrm{g})$ of field pea cultivars as affected by three different sowing methods

\begin{tabular}{|c|c|c|c|c|}
\hline \multirow{2}{*}{ Sowing methods } & \multicolumn{3}{|c|}{ Cultivars } & \multirow{2}{*}{ Mean } \\
\cline { 2 - 4 } & Local & Italian & Sel-190 & \\
\hline Broadcasting & 132.11 & 167.18 & 169.31 & $\mathbf{1 5 6 . 2 0 ~ c}$ \\
\hline Drilling & 140.02 & 158.79 & 183.79 & $\mathbf{1 6 0 . 8 7}$ b \\
\hline Ridge & 164.27 & 168.43 & 194.67 & $\mathbf{1 7 5 . 7 9}$ a \\
\hline Mean & $\mathbf{1 4 5 . 4 7} \mathbf{c}$ & $\mathbf{1 6 4 . 8 0} \mathbf{b}$ & $\mathbf{1 8 2 . 5 9}$ a & - \\
\hline
\end{tabular}

\begin{tabular}{|l|l|l|l|}
\hline & Sowing methods (M) & Cultivars (C) & $\mathbf{M} \times \mathbf{C}$ \\
\hline S.E. & 3.94 & 3.94 & 6.82 \\
\hline LSD 0.05 & 8.35 & 8.35 & 14.46 \\
\hline LSD 0.01 & 11.50 & 11.50 & - \\
\hline
\end{tabular}

Values followed by same letters do not differ significantly at 0.05 probability level

The results pertaining to seed yield of field pea cultivars as affected by different sowing methods are shown in the below given (Table 7). Statistical analysis suggested significant variation in seed yield of field pea due to sowing methods, cultivars as well as by the interaction of sowing methods $\times$ cultivars $(\mathrm{P}<0.05)$. The results indicated that seed yield of field pea was highest $4109.86 \mathrm{~kg} \mathrm{~h}^{-1}$ under ridge sowing method; and seed yield $\mathrm{kg} \mathrm{ha}^{-1}$ reduced to $3560.70 \mathrm{~kg}$ and $3054.86 \mathrm{~kg}$ under drilling method and broadcasting method, respectively. In case of cultivars, the seed yield was highest $3860.30 \mathrm{~kg} \mathrm{ha}^{-}$ 1 , followed by cultivar "Italian" cultivar $3703.36 \mathrm{~kg} \mathrm{ha}^{-1}$ and the lowest seed yield $3161.80 \mathrm{~kg} \mathrm{ha}^{-1}$ was observed in 'Local' cultivar. Treatment interaction (Ridge method $\times$ 'Sel-190' cultivar) resulted in maximum seed yield $\mathrm{kg} \mathrm{ha}^{-1} 4642.60 \mathrm{~kg}$ and interaction (Broadcasting method $x$ 'Local' cultivar) resulted in lowest seed yield $2839.10 \mathrm{~kg} \mathrm{ha}^{-1}$. The crop sown under ridge method resulted in quality produce and hence heavier seeds accumulated a higher seed yield $\mathrm{kg} \mathrm{ha}^{-1}$ as compared to rest of the sowing methods; and this was mainly associated with increased seed index value. The LSD test indicated that field pea cultivars "Italian" and 'Sel-190' showed similarity $(\mathrm{P}>0.05)$ in case of seed yield $\mathrm{kg} \mathrm{ha}^{-1}$; while a linear difference in seed yield was found among sowing methods.

\section{Discussion}

The present study showed that all the growth, yield traits in field pea cultivars were significantly $(\mathrm{P}<0.05)$ influenced by sowing methods. The crop sown under ridge methods produced $89.70 \%$ seed germination, 7.35 branches plant $^{-1}, 29.45$ pods plant ${ }^{-1}, 5.92$ seeds pod $^{-1}, 6.94 \mathrm{~kg}$ fresh pod yield $\mathrm{kg} \mathrm{plot}^{-1}, 179.79 \mathrm{~g}$ seed index and $4109.86 \mathrm{~kg}$ seed yield $\mathrm{ha}^{-1}$. The crop sown by drilling method produced $86.14 \%$ seed germination, 6.19 branches plant $^{-1}, 25.76$ pods plant ${ }^{-1}, 5.28$ seeds pod $^{-}$ ${ }^{1}, 6.18 \mathrm{~kg}$ fresh pod yield plot $^{-1}, 160.87 \mathrm{~g}$ seed index and $3560.70 \mathrm{~kg}$ seed yield ha ${ }^{-1}$. The peas sown by broadcasting method produced lowest values for all the traits. The cultivar effect indicates that 'Sel-190' cultivar produced $86.04 \%$ seed germination, 6.52 branches plant $^{-1}, 27.07$ pods plant ${ }^{-1}, 6.15$ seeds pod $^{-1}, 7.20 \mathrm{~kg}$ fresh pod yield plot ${ }^{-1}, 182.59 \mathrm{~g}$ seed index and $3860.30 \mathrm{~kg}$ seed yield $\mathrm{ha}^{-1}$. The ridge 
sowing method proved to be superior over drilling and broadcasting with highest seed yield $4109.86 \mathrm{kgha}^{-1}$ while among cultivars, the higher seed yields were recorded in cultivars 'Sel-190' $3860.30 \mathrm{~kg}$ $\mathrm{ha}^{-1}$ and 'Italian' $3703.33 \mathrm{~kg} \mathrm{ha}^{-1}$ than 'Local' cultivar.

Table 7. Seed yield $\left(\mathrm{kg} \mathrm{ha}^{-1}\right)$ of field pea cultivars as affected by three different sowing methods

\begin{tabular}{|c|c|c|c|c|}
\hline \multirow{2}{*}{ Sowing methods } & \multicolumn{3}{|c|}{ Cultivars } & \multirow{2}{*}{ Mean } \\
\cline { 2 - 4 } & Local & Italian & Sel-190 & \\
\hline Broadcasting & 2839.10 & 3123.70 & 3201.80 & $\mathbf{3 0 5 4 . 8 6} \mathbf{~ c}$ \\
\hline Drilling & 3129.00 & 3816.60 & 3736.50 & $\mathbf{3 5 6 0 . 7 0} \mathbf{b}$ \\
\hline Ridge & 3517.30 & 4169.70 & 4642.60 & $\mathbf{4 1 0 9 . 8 6}$ a \\
\hline Mean & $\mathbf{3 1 6 1 . 8 0} \mathbf{b}$ & $\mathbf{3 7 0 3 . 3 3} \mathbf{a}$ & $\mathbf{3 8 6 0 . 3 0} \mathbf{a}$ & - \\
\hline
\end{tabular}

\begin{tabular}{|c|c|c|c|}
\hline & Sowing methods (M) & Cultivars (C) & M×C \\
\hline S.E. \pm & 100.23 & 100.23 & 160.21 \\
\hline LSD 0.05 & 218.48 & 218.48 & 351.62 \\
\hline LSD 0.01 & 338.79 & 338.79 & - \\
\hline
\end{tabular}

Values followed by same letters do not differ significantly at 0.05 probability level

These results are in agreement with those of Sharma \& Rajput [8] reported that sowing methods has significant impact on the growth and yield attributes of pea and the yield responses varied markedly under different tillage methods and sowing techniques. El-Habbasha et al. [10] concluded that sowing of peas on ridges in line resulted in higher yields as compared to other planting techniques. The Varshney [11] found that sowing methods and spacing between rows and plants affects the crop performance significantly. The Devi et al. [12] reported that inter and intra row spacing and sowing methods have significant effect on the performance of field peas. The Ghaffar [13] reported that that raised bed under wider row spacing proved to be the superior sowing pattern as compared to flatbed system, but row spacing beyond $(60 \mathrm{~cm})$ did not show economic impact on pod yield because of reduced plant population. Hence, sowing of peas in raised bed system at $60 \mathrm{~cm}$ row spacing was considered as an effective sowing pattern. The Kuczkowski et al. [7] used broadcasting, drilling ridges and dibbling of seeds were used. The results showed that regardless the cultivars of common pea and spacing arrangements, drilling seeds on ridges proved to be effective in producing higher yields in pea as compared to other management techniques. The Gan et al. [14] suggest that ridge-furrow systems are an innovative approach for increasing crop water availability, improving soil productivity, and enhancing food security for arid and semiarid rain-fed areas. The Rasaei et al. [15] reported that planting peas on ridges produced higher yields than planting on flat beds; while the pea cultivars performed variably under different environments. In another study, El-Habbasha et al. [10] from Egypt reported that the closer spacing gave maximum total and early pod yields in peas, while wide spacing gave larger pods and number of seeds pod $^{-1}$, while Ikhtiaruddin et al. [16] in Bangladesh determined high pod yields of peas under $(30 \mathrm{~cm})$ row spacing. In contrast, Varshney [11] reported no significant variation in seed yield between different cultivars or spacings or planting patterns in peas. Similarly, Vittum et al. [17] 
examined the effects of planting patterns on the productivity of field peas and reported that as plants per acre increased, the yield per plant decreased; while Devi et al. [12] from India reported that yield was significantly higher in plots with narrower row spacing whereas yield was highest at $(15 \mathrm{~cm})$ intra-row spacing and Gritton et al. [18] reported that yields increased with increased population and decreased row spacing; greatest yields were obtained with the highest population grown in the narrowest rows. Moreover, Kargin et al. [19] suggested sowing by the row method $(30 \mathrm{~cm})$ on weed-free fields and by a wide-row method with $(45 \mathrm{~cm})$ interrow spacing on weedy fields. The Mankotia et al. [20] mentioned that growth of peas was significantly affected by sowing patterns. On the basis of comparative analysis of sowing methods experimented and adopted in other parts of the world, it was noted that ridge sowing proved to be the superior sowing method as compared to drilling and broadcasting sowing methods. Hence, sowing of field peas on ridges considered as an effective sowing pattern.

\section{Conclusions}

It was concluded that ridge sowing method proved to be superior over drilling and broadcasting sowing method with highest seed yield (4109.86 $\mathrm{kg} \mathrm{ha}^{1}$ ); while among cultivars, the higher seed yields were recorded in cultivar 'Sel 190' $(3860.30 \mathrm{~kg}$ $\mathrm{ha}^{-1}$ ) and 'Italian' (3703.33 $\left.\mathrm{kg} \mathrm{ha}^{-1}\right)$ than 'Local' cultivar.

\section{Authors' contributions}

Conceived and designed the experiments: AS Khetran \& ZA Mostoi, Performed the experiments: MA Kakar \& AS Khetran, Analyzed the data: ZA Mastoi \& R Khetran, Contributed reagents/ materials/ analysis tools: MUR Baloch, Wrote the paper: MS Mastoi.

\section{Reference}

1. Smart J (1998). Grain Legumes: Evolution and genetic resources. Cambridige University Press Cambridge UK 200 p.
2. Bianchini F \& Corbetta F (1976). The Complete Book of Fruits and Vegetables. New York Crown Publishers Inc USA Pp. 343-344.

3. Smith EC (2000). The vegetable gardener's bible: discover Ed's high yield W-O-R-D system for all North American gardening regions, Storey Books Pownal, VT, Pp. 1-3.

4. Zohary D \& Maria H (2000). Domestication of Plants in the Old World, third edition. Oxford University Press Pp. 106.

5. Achakzai AKK \& Bangulzai MI (2006). Effect of various levels of nitrogen fertilizer on the yield and yield attributes of Pea (Pisum sativum L.) cultivars. Pak J Bot 38(2): 331-340.

6. Hulse G (1994). Vegetable Production (Book) Food values of peas, John Willy and Sons New York.

7. Kuczkowski J, Kotecki A \& Kozak M (2006). The effect of sowing method on growth and yielding of narrow-leaf pea cultivars. Pt. 2. Chemical content and elements' yield. $J$ of Hort Sci 546(89): 207-219.

8. Sharma RK \& Rajput OP (1999). Crop geometry and nutrient management in pea (Pisum sativum L) + groundnut (Arachis hypogaea L) intercropping system. Indi J of Agro 41(2): 329-331.

9. Rodales F (2005). Commercial Vegetable Production Guides. Oregon State University Peas, http://www.oregonstate.edu.html.

10. El-Habbasha KM, Adam SM \& Rizk FA (2000). Growth and yield of pea (Pisum sativum L). Plants as affected by plant density and foliar potassium application. Egy J of Hort 23(1): 35-51.

11. Varshney JG (2001). Response of dwarf pea cultivars to dates of sowing and row spacings. Indi $J$ of Pulses Res 8(1): 33-35.

12. Devi D, Kumar R, Khippal A \& Dayal D (2002). Effect of different intra-row spacings on the growth of pea. Annals of Bio Ludhiana 11(1-2): 212-214. 
13. Ghaffar A (2008). Effect of sowing techniques on the growth and yield attribute of field pea cultivars M.Sc. Thesis submitted to Sindh Agriculture University Tandojam.

14. Gan Y, Siddique KHM, Turner NC, Gang X, Yi Niu J, Yang C, Liu L \& Chai Q (2013). Chapter Seven - Ridge-Furrow Mulching Systems-An Innovative Technique for Boosting Crop Productivity in Semiarid Rain-Fed Environments. Advances in Agronomy 118: 429-476.

15. Rasaei AM, Ghobadi G \& Ghobadi M (2012). Effect of supplemental irrigation and plant density on yield and yield components of peas (Pisum sativum L.) in Kermanshah Region. Ameri-Eur J Agric \& Environ Sci 12(3): 352-357.

16. Ikhtiaruddin M, Sirajui Karim AJM, Khaleque M \& Egashira MK (2001). Effects of Row Space and Fertilizer Nitrogen Level on the Yield and Quality of Short Duration Garden Pea
Grown on a Clay Terrace Soil of Bangladesh. J Fac Agric Kyushu Univ 45(2): 601-610.

17. Vittum MT, Lathwell DJ, Peck NH \& Sayre CB (2001). Effect of Variable Row Spacings and Plant Populations on Peas Grown for Processing and on the Subsequent Crop of Alfalfa1. Agron J 50: 577-580.

18. Gritton ET \& Eastin JA (2002). Response of Peas Pisum sativum L. to Plant Population and Spacing. Agron J 21(1/2): 248-250.

19. Kargin IF, Tarakin IP, Kuznetsov IS \& Artemev AA (2003). Productivity of pea on leached chernozem the foreststeppe in the Volga Region. Russ Agric Sci (1): 6-9.

20. Mankotia BS, Negi PS \& Singh B (2003). Influence of pea (Pisum sativum $\mathrm{L}$ ) intercropping and fertility levels on Gobhi sarson (Brassica napus L) in mid-hill conditions of Himachal Pradesh. Himachal J of Agric Res 20(12): 5-11. 